
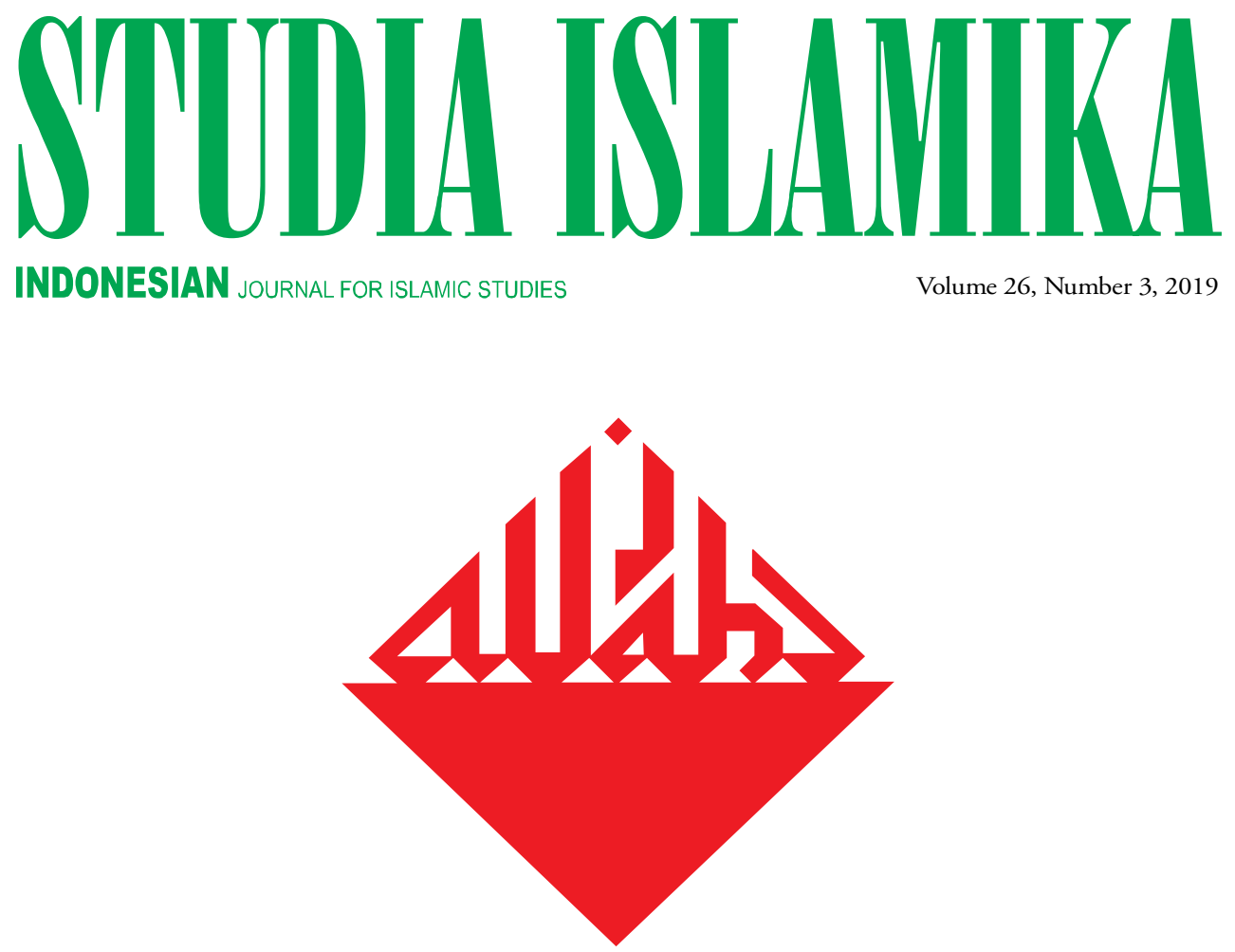

Pretext for Religious Violence in Indonesia: An Anthropolinguistic Analysis of Fatwas on Ahmadiyya Fariz Alnizar

Food and Local Social Harmony:

Pork, Communal Dining, and Muslim-Christian Relations in Flores, Indonesia Yohanes S. Lon \& Fransiska Widyawati

Religious Pluralism Revisited: Discursive Patterns of the Ulama Fatwa IN INDONESIA AND Malaysia Syafiq Hasyim

The Decline of Traditional Learning Methods in Changing Indonesia:

Trends of Bandongan-Kitäb Readings in Pesantrens Ervan Nurtawab 
STIUDLA ISLAMIIIKA 



\section{SIIIDIA ISLAMIIIKA}

Indonesian Journal for Islamic Studies

Vol. 26, no. 3, 2019

EDITOR-IN-CHIEF

Azyumardi Azra

MANAGING EDITOR

Oman Fathurahman

EDITORS

Saiful Mujani

Jambari

Didin Syafruddin

Jajat Burhanudin

Fuad Jabali

Ali Munhanif

Saiful Umam

Dadi Darmadi

Jajang Jahroni

Din Wahid

Euis Nurlaelawati

INTERNATIONAL EDITORIAL BOARD

M. Quraish Shihab (Syarif Hidayatullah State Islamic University of Jakarta, INDONESIA)

M.C. Ricklefs (Australian National University, AUSTRALIA)

Martin van Bruinessen (Utrecht University, NETHERLANDS)

John R. Bowen (Washington University, USA)

M. Kamal Hasan (International Islamic University, MALAYSIA)

Virginia M. Hooker (Australian National University, AUSTRALIA)

Edwin P. Wieringa (Universität zu Köln, GERMANY)

Robert W. Hefner (Boston University, USA)

Rémy Madinier (Centre national de la recherche scientifique (CNRS), FRANCE)

R. Michael Feener (National University of Singapore, SINGAPORE)

Michael F. Laffan (Princeton University, USA)

Minako Sakai (The University of New South Wales, AUSTRALIA)

Annabel Teh Gallop (The British Library, UK)

Syafaatun Almirzanah (Sunan Kalijaga State Islamic University of Yogyakarta, INDONESIA)

\section{ASSISTANT TO THE EDITORS}

Testriono

Muhammad Nida' Fadlan

Abdullah Maulani

ENGLISH LANGUAGE ADVISOR

Benjamin J. Freeman

Daniel Peterson

Batool Moussa

ARABIC LANGUAGE ADVISOR

Tb. Ade Asnawi

\section{COVER DESIGNER}

S. Prinka 
STUDIA ISLAMIKA (ISSN 0215-0492; E-ISSN: 2355-6145) is an international journal published by the Center for the Study of Islam and Society (PPIM) Syarif Hidayatullah State Islamic University of Jakarta, INDONESIA. It specializes in Indonesian Islamic studies in particular, and Southeast Asian Islamic studies in general, and is intended to communicate original researches and current issues on the subject. This journal warmly welcomes contributions from scholars of related disciplines. All submitted papers are subject to double-blind review process.

STUDIA ISLAMIKA has been accredited by The Ministry of Research, Technology, and Higher Education, Republic of Indonesia as an academic journal (Decree No. 32a/E/KPT/2017).

STUDIA ISLAMIKA has become a CrossRef Member since year 2014. Therefore, all articles published by STUDIA ISLAMIKA will have unique Digital Object Identifier (DOI) number.

STUDIA ISLAMIKA is indexed in Scopus since 30 May 2015.

Editorial Office:

STUDIA ISLAMIKA, Gedung Pusat Pengkajian

Islam dan Masyarakat (PPIM) UIN Jakarta,

Jl. Kertamukti No. 5, Pisangan Barat, Cirendeu,

Ciputat 15419, Jakarta, Indonesia.

Phone: (62-21) 7423543, 7499272, Fax: (62-21) 7408633;

E-mail: studia.islamika@uinjkt.ac.id

Website: http://journal.uinjkt.ac.id/index.php/studia-islamika

Annual subscription rates from outside Indonesia, institution: US\$ 75,00 and the cost of a single copy is US\$ 25,00; individual: US\$ 50,00 and the cost of a single copy is US\$ 20,00 . Rates do not include international postage and handling.

Please make all payment through bank transfer to: PPIM, Bank Mandiri KCP Tangerang Graha Karnos, Indonesia, account No. 101-00-0514550-1 (USD),

Swift Code: bmriidja

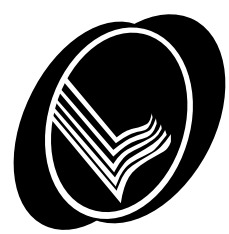

Harga berlangganan di Indonesia untuk satu tahun, lembaga: Rp. 150.000,-, harga satu edisi Rp. 50.000,-; individu: Rp. 100.000,-, harga satu edisi Rp. 40.000,-. Harga belum termasuk ongkos kirim.

Pembayaran melalui PPIM, Bank Mandiri KCP Tangerang Graha Karnos, No. Rek: 128-00-0105080-3 


\section{Table of Contents}

\section{Articles}

417 Fariz Alnizar

Pretext for Religious Violence in Indonesia:

An Anthropolinguistic Analysis

of Fatwas on Ahmadiyya

445 Yohanes S. Lon \& Fransiska Widyawati

Food and Local Social Harmony:

Pork, Communal Dining, and Muslim-Christian

Relations in Flores, Indonesia

475 Syafiq Hasyim

Religious Pluralism Revisited:

Discursive Patterns of the Ulama Fatwa

in Indonesia and Malaysia

511 Ervan Nurtawab

The Decline of Traditional Learning Methods

in Changing Indonesia:

Trends of Bandongan-Kitāb Readings in Pesantrens

543 Jamaluddin

Al-Shabakāt al-ijtimā‘̄ìyah wa al-fikrīyah

bayn muslimī Lombok wa Sumatera:

Dirāsah fī tuḥfah wa makhṭūṭ Sasak 


\section{Book Review}

585 Muhammad Nida' Fadlan

Lebih dari Sekedar Katalog Manuskrip:

Jejak Intelektualisme Islam di Mindanao

\section{Document}

603 Ismatu Ropi

Whither Religious Moderation?

The State and Management of

Religious Affairs in Contemporary Indonesia 


\title{
Ervan Nurtawab \\ The Decline of Traditional Learning Methods in Changing Indonesia: \\ Trends of Bandongan-Kitāb Readings in Pesantrens
}

\begin{abstract}
This article examines the marginalization of the traditional pesantren educational system and how the system finds a way to be recognized as equal in contemporary Indonesia. This study is mainly based on the author's observation of practices in Tafsīr al-Jalālayn pedagogies in traditional and modern West Javanese pesantrens and the kitāb reading tournament, with in-depth interviews of some related figures and teachers, during the periods 2015-2017. This article argues that the marginalization of the educational system since the coming of modernization in the early twentieth century continues to happen up to the end of the century. The graduates of the traditional institutions keep left behind, and that the traditional pesantren system is merely recognized as a type of non-formal education. The twentyfirst century period witnessed attempts from the Indonesian government through the Ministry of Religious Affairs to equalize the kitāb-based learning in the traditional milieu. By so doing, the graduates are expected to receive equal rights for pursuing their education or looking for a career.
\end{abstract}

Keywords: Islamic Pedagogy, Tafsìr al-Jalālayn, Formal Religious Education, Pesantren, Yellow Book. 
Abstrak: Artikel ini mengkaji marjinalisasi sistem pendidikan pesantren tradisional dan bagaimana sistem tersebut mencari jalan untuk bisa diakui secara setara di periode Indonesia kontemporer. Kajian ini utamanya berdasarkan observasi penulis atas praktik-praktik pengajaran Tafsīr al-Jalālayn di pesantren-pesantren tradisional dan modern di Jawa Barat dan perlombaan membaca kitab kuning, ditambah dengan wawancara mendalam dengan tokoh dan guru terkait, selama periode 2015-2017. Artikel ini berargumen bahwa proses marjinalisasi sistem pendidikan tersebut terus berlanjut sejak datangnya modernisasi di awal abad ke dua puluh masehi hingga akhir abad tersebut. Para lulusan lembaga-lembaga tradisional tetap tertinggal, dan bahwa sistem pesantren tradisional hanya dianggap sebagai sebuah jenis pendidikan nonformal. Periode abad ke dua puluh satu masehi menyaksikan berbagai usaha dari pemerintah Indonesia melalui Kementerian Agama untuk menyetarakan pembelajaran berbasis kitāb di lingkungan tradisional. Dengan usaha tersebut, para lulusannya diharapkan menerima hak-hak yang sama untuk melanjutkan studi mereka atau mencari pekerjaan.

Kata kunci: Pedagogi Islam, Tafsìr al-Jalālayn, Pendidikan Diniyah Formal, Pesantren, Kitab Kuning.

ملخص: يبحث هذا المقال في قميش نظام التعليم للبيسانترين التقليدي، ومحاولته للحصول

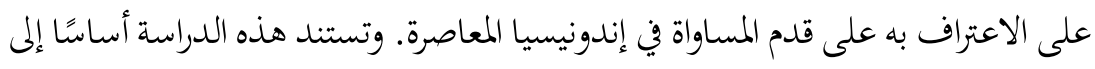

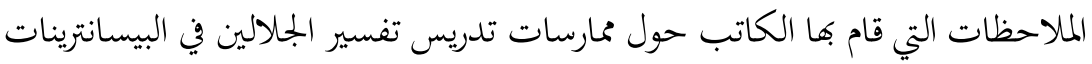

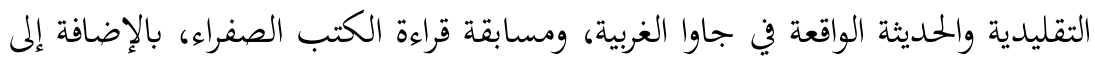

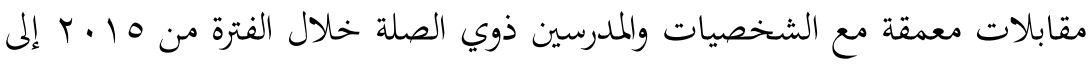

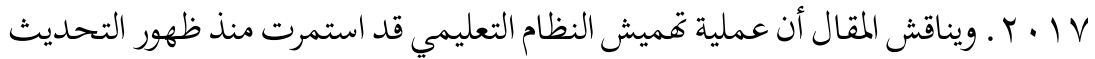

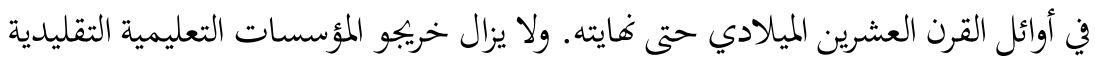

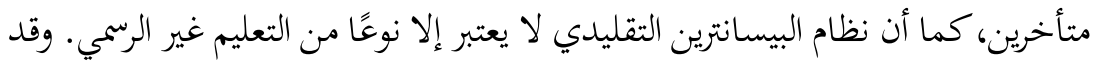

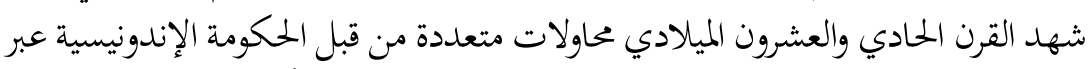

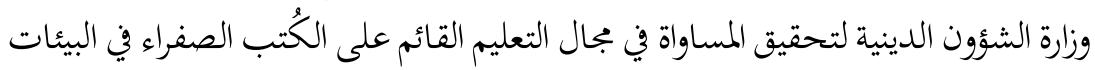

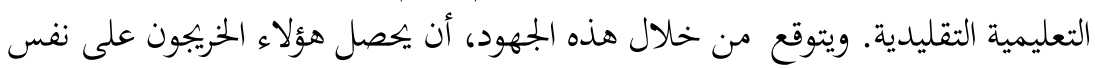

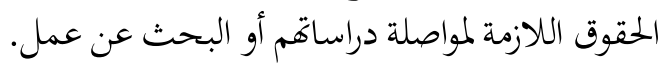

الكلمات المفتاحية: التربية الإسلامية، التفسير الجلالين، التعليم الديني الرسمي، البراني البيسانترين، الكتب الصفراء. 
$\mathrm{I}$ $\mathrm{n}$ this article, I argue that kitāb-based learning has contended with a process of marginalisation since the modernisation of the early twentieth century. Here, I introduce a form of kitāb-based learning, namely bandongan or bandongan kitäb, a distinctive pedagogy of traditional pesantren. This term confirms that in the pesantren, the $k i t a \bar{b}$ is the constitutive authorised reference for the study of Islam. It also confirms the kiai, the central figure of bandongan events, as the authoritative mediator of Islam in that environment. As Dhofier (1999, 30-31) notes, the teaching of classical Islamic texts through this form of pedagogy constitutes a main element of the pesantren tradition. Based mainly on my observation of practices in Islamic learning in two West Javanese pesantrens that offer different learning styles, i.e. traditional and modern, and the kitäb reading tournament and in depth interviews during the periods 2015-2017, this article therefore aims to describe the marginalisation of that method and how the pesantren system finds their way to be recognized as equal in contemporary Indonesia.

The bandongan kitäb has been marginalised and considered inferior in the mainstream state educational system in post-colonial Indonesia. In connection with the elaboration of that process, I use Tafsir alJalälayn, a representative kitāb used in the pesantren milieu, to explore how this marginalisation of the pedagogy took place. This does not mean that the Jalalayn is used only in the traditional pesantren milieu. Rather, the Jalälayn has acceptance as a textbook to serve the study of the Quran in some modern Islamic schools.

I trace how modernisation resulting from Westernisation and Islamic modernism in Egypt greatly influenced development of Islamic education in colonial and post-colonial Indonesia. In the early twentieth century, the development of Islamic education in Indonesia was marked by the emergence of Islamic schools that in many ways adopted elements of Western educational styles, or the modernised curriculum of the Azhar University. In this period, some Muslim groups developed new ways of handling religious education, not only to deepen religious piety, but also to encourage career orientations and professions in nonreligious fields of expertise. Furthermore, modernisation introduced a new school management structure, the foundation, to replace structures under the domain of an individual figure or family. Reception of modernised-education has greatly affected the way in which religious schools are managed in a professional way. 
The state and its educational policies have been closely involved in the reception of modernised education. In the first decade of postIndonesian independence, an issue in religious education was how Muslim religious education could be run independently by the Ministry of Religious Affairs, rather than being controlled by the Ministry of Education. Muslims successfully proposed formation of the Ministry of Religious Affairs, and this Ministry was established on 3 January 1946 (Panitia Hut ke-XXVII Departemen Agama RI 1973, 13).

The Ministry of Religious Affairs became the bureaucratic mechanism for religious education to be protected and develop in Indonesia. The Ministry's aim to equalise religious education encouraged Islamic institutions, especially traditional pesantrens, to modernise schoolmanagement and adopt the madrasah system, with standardised classroom styles and curriculums. In 1949, attempts to equalise standardised religious education with secular education were successful. Since then, two educational mainstreams have been officially acknowledged in Indonesia, one under the Ministry of Religious Affairs and the other under the Ministry of Education and Culture (Latif 2008, 258-59).

The bandongan kitāb suffered in these transformative processes. It was criticised because this learning style is difficult to standardise. First, this learning style has typically thrived under the domain of kin groups, a social formation that is problematic against the background of a bureaucratic state. Second, this learning style does not fit the subjectbased classroom style. Furthermore, the goal of learning is not oriented to seek a profession or occupation. In other words, the educational values of modern Indonesia do not favour kitäb-based learning, resulting in a state of inequality where social spaces for this learning practice are marginalised by modernisation.

But remarkably this marginalisation process has been resisted in unexpected ways and this research is concerned with examples of such resistance, of which two are important. The first, discussed later in this article, has been government-led. In the early twenty-first century, the Ministry of Religious Affairs attempted to equalise kitāb-based learning in the state educational system. By obtaining educational equality, graduates of the pesantrens that engage in kitāb-based learning had educational opportunities to develop their expertise and career.

The second resistance to educational inequality was the advocacy for traditional learning styles launched by some Indonesian Islamic 
figures concerned that the bandongan kitāb be acknowledged as a legitimate method for the study of Islam. One figure that attracted wide acceptance in Indonesia, especially in the West-Javanese province, is Ahmad Makki, who is known by the title Mama Ajengan or Mama, a popular title for a religious teacher in the Sundanese cultural region. He runs a traditional pesantren in Sukabumi and operates a printing company to supply the kitäb loghatan.

The term "kitāb loghatan" here approximately means "languaging books." It commonly refers to the re-prints of Islamic texts in Arabic with additional translations in Southeast Asian regional languages like Malay or Indonesian, Javanese, Sundanese or Madurese which placed diagonally below the main tex. Those translations are written using modified Arabic-based scripts called Jawi for Malay or Indonesian language and Pegon for other languages, i.e. Javanese, Sundanese and Madurese. This kitāb is also popular with the name "kitāb jenggot (beard book)" for those translation are placed diagonally in each word of the main text, looking like beard. I use the term "kitäb loghatan" on the grounds that local people where I met during observations identify the book with that name.

\section{Islamic Education and Religious Authority}

In connection with the way in which I look at the problem of inequality faced by the kitäb-based learning, my focus is on Islamic pedagogical practices and how these practices and methods in Islamic learning reflect contestation of religious authorities in contemporary Indonesia. Some works on this subject then allow us to locate pedagogy in social change on a large scale and the emergence of a differentiated field of religious education in which the Jalallayn is part.

Some that can be listed in this regard are authored by Yunus (1979), Steenbrink (1986), Dhofier (1999) and Azra (2003). Yunus' work was previously published in 1960 . Here, I use his second edition published in 1979 where, as its publisher (p. 9) notes, this edition was revised to comply with the Enhanced Spelling System (Ejaan Yang Disempurnakan, or EYD). As for Steenbrink's work, I use its Indonesian version published in 1986 which was based on his dissertation in Dutch language submitted to Nijmegen Catholic University in 1974. Dhofier's work, on the other hand, was firstly published in 1982 in Indonesian language. I use his later edition that was published in English in 1999. 
Regarding Azra's work, this 2003 edition is updated and translated version of his thesis submitted to Columbia University in 1988.

It can be said that the work of Yunus has gained a wide attention among scholars in the way that he presented important data on the list of textbooks prescribed in the Indonesian Islamic schools' curricula, their learning processes and development orientations. He has documented the way modernisation coming from the Dutch-sponsored schools and the modernized-Azhar curriculum in Egypt has played a pivotal role in giving more orientation to the conduct of Islamic education. He observed that the Sumatran Islamic schools tended to be more open to modernisation. Meanwhile, traditional learning found its stronger basis in pesantren institutions in Java, especially in both central and eastern parts of the Java Island. This work is among the important sources for me to re-construct the profile of the kitäb-based learning in the state educational system.

The work of Steenbrink (1986), on the other hand, presents other aspects in the development of Islamic education in modern Indonesia. This period is when Islamic educational institutions in the region have extensively received a great influence of modernity. In looking at the effect from this modernisation, he notes that the colonial Indonesia witnessed the emergence of other types in religious education, i.e. the madrasah system and the conduct of religious education in public schools, aside from the pesantren system that has been previously established.

In post-colonial Indonesia, Muslim leaders struggled to have religious affairs served as part of the state administration. This effort was successful with the formation of the Ministry of Religious Affairs that also administer religious education. Steenbrink observed what he has indicated as a convergence project where the Ministry of Religious Affairs pushed religious education to be equal to secular education that is administered by the Ministry of Education. In doing so, he notes, they encouraged the pesantren institutions to receive a modernisation in their school management as part of standardization. In addition, he also highlighted the emerging trend in the post-colonial period when the graduates of higher education increasingly received social acceptance in the society. Steenbrink notes that the transition from the kiai to Doctorandus (Drs.) is regarded as one of the important aspects that obviously emerged in Islamic development after the Indonesian independence. 
Aside from both Yunus' and Steenbrink's works above, Dhofier's work (1999) on the role of the kiai in the maintenance of the pesantren and traditional Islam in Java is the classical one. This work is based on fieldwork conducted between 1977 and 1978 in two pesantrens, i.e. Tebuireng and Tegalsari. Aside from Dhofier's work, Azra's work on the rise and decline of the Minangkabau surau is also considered the very important one. As expanded from his thesis in Columbia University in 1988, he explores the role of the surau as an institution in maintaining traditional education in the West Sumatra, with particular eyes to their responses and transmission to the modernity. Azra sees that the Minangkabau surau are very difficult to preserve when accepting modernisation. Their characteristics as a traditional institution no longer exist once their institutions become modernized. Meanwhile, the pesantren system in Java found its strong basis to survive whey they have also accepted modernisation.

Some scholars then produced works that greatly contribute to understanding the current Islamic education in Indonesia. Hefner and Zaman (2007), for example, have compiled some articles from scholars whose research subjects focus on Islamic education. One chapter of this book, entitled "Pesantren and Madrasa: Muslim Schools and National Ideals in Indonesia”, is authored by Azra, Afrianty and Hefner (2007). They bring to light the structure and variations in Islamic education in modern Indonesia and how their development connects to changing socio-political conditions in the state and society.

Hefner (2009) then edited the book that aims to shed light on variations and politics of Muslim education in five countries in the Southeast Asian region, i.e. Indonesia, Malaysia, Thailand, Cambodia, and the Philippines. In his introduction, Hefner highlights some connections between the development of Islamic education in Southeast Asia and that in the Middle East. He (p. 6) suggests that the historical aspect of Islamic education in Southeast Asia has more equivalent with the development of Islamic education in the Middle East in medieval times.

Regarding the way in which scholars look at contestations between religious authorities in Indonesia, Kaptein $(2004,115)$ notes that religious authorities in Muslim communities can be embedded in many patterns, those being in religious texts, individuals, groups of persons or institutions. They have served as the representative mediators of Islam. 
These patterns of religious authority are related to each other in the sense that the presence of one pattern in a given community has something to do with the remainders. For example, the acceptance of certain texts depends on the platform of related individuals. When authority is embedded in group or institution, any individuals involved are bound to conform to the logic of the community or institution in which they are accepted as part of the authority.

Authority can be manifest in different patterns, but it has always been contested following to changing social conditions or emerging new thoughts. This is obviously the case with the way in which kitäb as the representative mediator of Islam has been challenged with a new way of learning Islam, that is through the production of periodicals run by modernist Muslim groups.

In the early twentieth century, the use of the printing-press was typical among the modernist Muslim groups. The periodical alManār, initiated by Abduh and Rida in 1898, has greatly inspired the emergence of al-Imām which was firstly published in 1906 among the Malay-Muslim community in Singapore. This periodical was primarily pioneered by four members of the community: Mohd. Tahir ibn Jalaluddin, Sayyid Shaykh ibn Ahmad al-Hadi, Haji Abbas ibn Mohd. Toha, and Mohd. Salim al-Kalali. The periodical al-Imām has in turn inspired the emergence of al-Munir in 1911. These three periodicals belonged to the reform movement which sought the importance of returning to the Quran and the actual practice of the Prophet Muhammad and leaving the blind imitation toward the longestablished schools of law. They managed to build Islamic schools that adopted elements of modernized educational styles to serve the need for a purified Islam and secular knowledge (Roff 1967, 56-66).

Focusing on the changing role of ulama in the early twentiethcentury Indonesia, Burhanudin (2010, 54-56) notes that the emergence of ulama had been determined by the existence of kitäbs as textbooks. Nevertheless, their role as the mediator of Islam began to be challenged with the development of printing-press, the use of roman script by which Muslim groups in urban areas propagated their Islamic ideas and thoughts. In the end, Burhanuddin states that modernity seems to have provided the ulama with the supporting tools and methods to more effectively define Islam in accordance with their Islamic perspectives and then enhance their religious authority. 
The changes of the late nineteenth and early twentieth century have contributed to the making of religious organizations in Indonesia, such as Muhammadiyah and Nahdlatul Ulama. However, Machasin (2010, 118) notes that the local ulamas felt like being marginalised in the decision making by the organization where they were based.

It has commonly happened that the local ulamas have maintained their stance on certain religious matters when they have different points of view with the institution with which they have been affiliated. Based on this point, we note that after the Indonesian independence the pesantren system where traditional learning is based then remains the domain of individual or kin group. Modernized-religious education then received equality in the state educational system. Meanwhile, traditional learning as belonging to the pesantren system is only acknowledged as non-formal education.

\section{Kitāb and Modern Education}

\section{in Pre-Colonial Indonesia: Tafsìr al-Jalälayn}

In this section, I explore the state of Islamic education in pre-colonial Indonesia in which the development has received much influence from Western modernisation and Islamic modernism in Egypt. The reception of modernisation caused a shift in orientations of the way in which Islamic education should be professionally managed. In this period, some Muslims groups have developed new ways of schooling in which orientation not only to deepen Islamic knowledge and piety, but also to seek a career as a professional teacher in Islamic studies or government officer.

In connection to the description of kitāb's position as a pedagogical tool in this period, I use Tafsìr al-Jalālayn as representing the symbol of educational equality. The fact is that the Jalalayn has been for centuries used to serve the study of the Quran in traditional education. The learning starts from the first page, then continues until the end of the book. In the coming of modernisation to Indonesia, the Jalālayn has received a certain level of acceptance among modernist Muslim groups that run Islamic schools. In that environment, learning process is managed in a effective and efficient way and strictly scheduled in a certain period of time. In their perspective, the use of kitāb as a source for Islamic learning must comply with the designed objectives of learning. Therefore, selection of verses is made to serve related subjects 
based on the curriculum. Classical Islamic texts are still important, but they are no longer used as the sole source to serve one subject as it has been a common practice in a traditional environment. The Jalalayn in this regard is a representative kitäb in the way in which modernisation has created a different way of handling kitābs for pedagogical purposes. As will be elaborated in the next section, there has been an increasing awareness among traditionalist Muslims in seeking equal opportunities for the graduates of the pesantren in the working places. Their struggle to seek educational equality in some ways encouraged the people of the pesantren to bring their learning tradition for a public display.

The Dutch colonial government designed an education system for Indonesian natives to meet the need for official vacancies in the Dutch colonial government. However, in 1888 the government refused to subsidise Islamic schools because they did not want to spend money for schools that, in their thinking, developed a flawed learning method where students were only trained to memorise Arabic texts without comprehension. Therefore, attempts to include Islamic education under the Dutch colonial system were unsuccessful. Hence, Islamic educators found ways to develop their tradition, and at the same time, many Islamic educators were open to adaptation of outside methods (Latif 2008; Steenbrink 1986). As Noer $(2010,37)$ notes, the Dutch colonial government only subsidised some Islamic schools that modernised their educational system in the 1930s.

In the early twentieth century there was a great shift within Muslim communities in the world, especially in Indonesia, as Islamic intellectuals engaged more thoroughly with intellectual currents in other fields, especially among urban Muslim communities. Federspiel (1970) and Noer (1980) state that the modernist-reformist movement led by Egyptian Muslim scholars, such as Muhammad Abduh (d. 1905) and Rashid Rida (d. 1935), inspired the emergence of similar movements elsewhere, which caused Muslim polarities that persist in early twenty century up to contemporary Indonesia. These modernistreformist Muslim groups sought a direct approach to the Quran and prophetic traditions in the following ways: reject blind imitations (taqlid); reject affiliation with a certain school of Islamic legal thought (madhhab), notably in Islamic jurisprudence and worship; avoid what they regarded as superstition and heresy; and to consider the kitäbs affiliated with certain schools of Islamic legal thought as old-fashioned. 
Regarding the latter, most kitābs were replaced with new Islamic works considered as adequate responses to changing social conditions and modern Quranic interpretations in light of imperialism and scientific development.

Yet it was not only theological differences that motivated this shift in authority, for modernist education also promoted new learning styles that diminished the authority and value of kitäbs as learning resources. The work of Yunus (1979 especially Chapter 3), which concerns developments in Sumatra, is useful for understanding these changes. In the older styles, of which bandongan is representative, children attended Quranic recitation training in a neighbourhood (mosque, Islamic school) where they learned how to perform basic religious obligations, for example making ablutions, praying, fasting, etc.

Bandongan is a popular word among the people of pesantren in Java, including the Sundanese cultural region, to identify a group event in Islamic learning. There is a similar word spelled as bandungan in the Sundanese cultural regions. Nevertheless, in Sukabumi where I observed the practice of traditional Islamic learning, the word balaghan, possibly derived from Arabic word "ballagha (to convey)" is used to identify a group event who pay attention to the teacher (kiai) reading some passages of the Arabic text with translation. As we find in a Javanese bandongan, such a group event can be set up for all levels of students to come. Otherwise, students are grouped based on their achievement in completing certain books to attend different bandongans. In practice, students do cross-legged sitting on the floor, paying attention to the $k i t a \bar{b}$ reading conducted by the teacher. Students keep silent during the event, holding the same book as the kiai brings on their lap and taking necessary notes. Any interruptions toward the teacher's reading would be socially taken as unsuitable behaviour.

Once students completed this basic education, many continued to follow the bandongan kitāb. Many students following this route would avoid non-religious studies. In this educational experience, which was performed under the supervision of a scholar in an institution that was owned by the scholar's family, students valued co-presence with the teacher as well as completion of kitäb as essential elements of the study experience. Durations of study were flexible, and generally long. Yunus $(1979,51)$ notes that a student normally spent up to 15 years completing all the bandongan kitäb before being socially accepted to 
teach or build an Islamic school. This long period of training was partly due to the need to accumulate qualifications sequentially, and the study of tafsir usually took place at an advanced level. Students were likely to be considered eligible to follow tafsir learning if they had completed bandongan kitāb at a lower level either in Arabic grammar or Islamic jurisprudence.

This educational form was challenged by the reformist/modernist innovations. When the Adabiyah school was established in 1909 in Padang, West Sumatra, it consciously adopted elements from Dutchsponsored schools. This school adapted the Minangkabau surau to the forms and values of Dutch-sponsored education, notably with use of classroom and such facilities as board, desks and chairs (for more detail on Minangkabau surau see Azra 2003). Islamic pedagogy was given decreasing emphasis in this school, which in turn led to disappearance of the traditional surau in the following years. From then up to 1930, Yunus (1979) explains that more modernised Islamic schools were built in this region, such as the Madrasah Diniah Padangpanjang in 1915, the Madrasah Sumatera Thawalib in 1921 and the Madrasah Persatuan Tarbiyah Islamiah in 1928.

The curriculum of the Madrasah Sumatera Thawalib also illustrates the changes. Up to and including the 1920s students were to understand the classical tafsir tradition in advance before they were introduced to the reform agenda in tafisir discourse. The Jalalayn, together with other classical tafsìrs, like Tafsìr al-Baydāwī or Tafsìr al-Khäzin, were still wellreceived textbooks for the tafsir subject. In the final grade, students read Tafsìr al-Manār authored by two prominent modernist scholars, Abduh and Rida. Things changed after the 1920s, and into the 1930s, classical kitābs were mostly no longer used at this school. Instead, their authority was replaced by new textbooks taken from contemporary publications of Azhar university scholars or prepared by figures who controlled the school (see also Steenbrink 1986, 46).

A similar critique of traditional kitäb-based learning is also provided by the biggest organisation representative of modernist Muslims, the Muhammadiyah. According to Muhammadiyah education policy, there was little value in pushing students to memorise Arabic text without gaining comprehension. Further, traditional teachers did not pay attention to student progress in a systematised and structural way (Wirjosukarto 1966, 120-23). 
A feature of the transition from traditional to modernised Islamic schooling was that students at modernised schools had more subjects to study as part of a structured progression. With the introduction of standardised curriculum, certain core subjects became compulsory, and other avenues of study were made redundant. Moreover, the progression whereby a student needed to complete a lower level of kitāb before seeking completion of other kitābs at a higher level was no longer part of the pedagogical structure. The goals and values of learning changed as well. Amongst these changing values was the value of completion, as completion of a kitāb was no longer the goal of learning in modernised schools. Furthermore, modern Islamic schools paid more attention to secular subjects, and the load of Islamic study was reduced.

The movement was not totally in one direction. There were traditionally-oriented Islamic schools that adopted elements of Western educational style while maintaining kitābs as a main element of education. The Madrasah al-Jam iyah al-Wasliyah is an example from this period. This institution was established in 1930 to directly adopt Dutch-sponsored education while maintaining affiliation with the Shafi'ite school (Steenbrink 1986, 79-80; Yunus 1979, 195). In this school, the Jalälayn served as an introduction to the tafsir subject at the secondary (thanawi) level, after which students could be eligible to take tafsīr subjects in higher grades, i.e. tertiary level or al-Qism al- $\bar{A} l i$, where they studied tafsìr works authored by al-Bayḍawī, al-Khāzin, alNasafī, and Ibn 'Abbās (Yunus 1979, 195-98).

Although the situation in Java resembled the Sumatran situation, there are important points of distinction. In Java, traditional Islamic education found a strong basis for support following the formation of the Nahdlatul Ulama (NU), the biggest organisation representative of traditionalist Muslims in Indonesia. Fealy (1998) notes that formation of this organisation indicates traditionalist resistance to marginalisation by modernists. This was especially the case in the exclusion of a traditionalist representative as part of the Indies' delegation to attend the al-Islam Congress in Hijaz in 1926. This event spurred traditional ulamas to protect their religious practices. In late January 1926, with the approval of K.H. Hasjim Asjari, K.H. Wahab Chasbullah invited a number of leading traditionalist figures to meet in Surabaya. This meeting was convened to approve a delegation from the traditionalist group to travel to Mecca in an attempt to protect traditional religious practices. 
Based on its committed defence of traditional Islamic learning (Dhofier 1999, 30-31), the NU becomes a 'home' for institutions dedicated to traditional kitāb-based learning. In comparing Javanese pesantren and Minangkabau surau responses to modernisation, Azra $(2003,26)$ argues that the involution of Javanese culture enabled Muslim communities to absorb foreign elements without necessarily losing Javanese identity. This strong culture has enabled Javanese pesantrens to continue to the present time. In traditional educational institutions (pesantren) in Java, the Jalälayn remains the primary entry point to tafsir discourse, and the bandongan remains an authoritative pedagogical form in those institutions, which remain attractive to many students.

\section{Kitāb-based Learning among Modernist Muslim Groups}

Interestingly, although the Jalālayn clearly belongs to the corpus of traditional Islamic authority, its reception extended beyond traditionalist circles. Despite marginalisation of bandongan learning, the Jalälayn received wide acceptance among modernist Muslim groups. It is on the curriculum of some modernist institutions (minus the bandongan pedagogical practice). My explanation for this is twofold. First, the Jalālayn formed part of the educational upbringing of many influential modernist scholars, and in this sense, their understanding of the tradition of Quranic tafsir-learning is inseparable from this one text. Second, their understanding of that tradition gives a particular place and status to the Jalalayn. This specific text is iconic of that tradition, and is difficult to be replaced by another, for the Jalälayn (independent of the pedagogical style through which it is taught) has become a symbol of the general tradition of Islamic learning, of which modernist institutions are very respectful. In the following, I describe how the Jalalayn has found a place in the curriculum of institutions belonging to two Muslim modernist organisations, i.e. the Muhammadiyah and the Persatuan Islam (Persis).

As Wirjosukarto $(1966,119)$ notes, the Pondok Muhammadijah was established in Yogyakarta in 1920. This institution is a continuation of the Qism al-Arqa initiated by K.H.A. Dahlan, founder of the Muhammadiyah organisation, the biggest organisation representing modernist Muslims in Indonesia. After the institution's name was changed to Pondok Muhammadijah, general subjects were taught 
alongside religious subjects, and these changes introduced new practices and methods in Islamic learning. The Pondok Muhammadijah, now known as the Madrasah Mu'allimin Muhammadiyah, is regarded as the first religious educational institution run under the modern-based administration in Yogyakarta. This institution adopted a modern learning style where students study in classrooms, sitting on chairs, and using tables as a working surface. Meanwhile, teachers were equipped with chair and table as well as a board. This was clearly not an environment for bandongan.

Wirjosukarto (1966, 123) shows how the Muhammadiyah curriculum was partly shaped by the kitäb-based tradition from which the group emerged in 1912. Aside from general subjects, the Quran and the Hadith, the Pondok Muhammadijah taught some kitābs of the Shafi'ite school, al-Ghazalī's works in Sufism, kitäbs authored by scholars who follow the doctrine of the Abl al-Sunnah wa al-Jama'ah (Adherents to the Prophetic Tradition and the Community) as well as the Jalälayn.

Yet being a modernist institution, Wirjosukarto $(1966,123)$ notes that the Pondok Muhammadijah introduced such modernist works as Risälat al-tawhìd (the theology of unity) authored by Muhammad Abduh, some fiqh works designed using a new method of presentation, Tafsìr al-Manār (the interpretation of beacon) and other kitābs that supported the reform agenda. Nevertheless, it is striking that the Jalälayn, by virtue of its symbolic value, was retained in the curriculum.

A different tendency concerning the reception of kitäb among modernist groups emerge in Persis-affiliated pesantren. This group is highly relevant to this study, as a Persis pesantren was a field site for this research. Development of Islamic education in the Persis organisation commenced in 1936 with the formation of an educational institution known as Pendidikan Islam, or Islamic Education. This formation was partly a response to the need of Islamic schools in the district of Bandung to provide religious training integrated in the school curriculum. A. Hassan (d. 1958), one of the founders of this organisation, arranged the pesantren system, popularly called the Pesantren Persis, that later became the benchmark for Persis-affiliated educational institutions (Noer 1980, 101-2).

The Persatuan Islam pursued the reform agenda by encouraging Muslims to take a direct approach to the Quran and hadith, to reject 
blind imitation (taqlid), to release themselves from strict affiliation with any single madhhab and to allow a mixed legal positioning between two legal opinions (talfi $q$ ) as long as this positioning had a proper basis in the Quran and authentic Hadith. As Bachtiar (2012, 97-98) notes, these strict principles greatly influenced the way Persis members made selection of kitābs for use in pedagogical practices. Kitābs were mostly replaced by new textbooks. Federspiel (2001, 66-69) notes that the modernist perspective contributed to the emergence of new religious literary genres using the vernacular (use of Indonesian language in this regard) and increasing use of Roman script in production of the works. During the early twentieth century, Islamic literature was primarily provided in Arabic or in Arabic-based scripts.

Although tafsir was included as part of the curriculum in Persis pesantren in the pre-colonial Indonesian period, the Jalalayn was not among the textbooks taught. This continued at least until the period of K.H.E. Abdurrahman, who became the head of Persis from 1962 to 1983. As Bachtiar (2012) notes, this man is regarded as greatly contributing to the institutionalisation of Islamic education in the Persatuan Islam milieu. After speaking with two of his disciples, I understand that K.H.E. Abdurrahman did not use the Jalalayn in his tafsir classes. Instead, he taught the Tafsir Ibn Kathir. ${ }^{1}$

There was an interesting development after Abdurrahman. According to Rosyidin (2009), the Jalālayn appeared as a prescribed textbook in the curriculum issued by the central board of the Persis organisation in 2005. This work was included as one of the references for students in the thanawi-dinīyah wustá level (equal to junior high school level). For Bachtiar (2012, 99), this reception of the Jalālayn in the Pesantren Persis milieu indicated the value of plurality among Persis members, revealing the co-existence of various approaches to Islamic scholarship. It indicates that there are varying ways of affiliating with tradition in Persis. While some Persis members advocate forms of modern learning, ${ }^{2}$ others accept and advocate the use of kitäbs in the classroom. Reception of the Jalälayn, and other traditional kitābs, indicates the intensive socio-cultural contact of Persis members with traditional education. A good example is Ustaz Aceng Zakaria, current chair of the Persis organisation. In his childhood he followed bandongan kitäb delivered by his parents, who were teachers, for whom he acted as secretary of the study program. His parents at the time delivered 
the bandongan Hikam, the book on Sufism authored by Ibn 'Ațāillāh al-Sakandarī (d. 1310). Ustaz Aceng completed this bandongan two or three times.

Ustaz Aceng Zakaria later studied under his cousin, Ajengan Uyum, with whom he undertook kitäb-gatherings, such as Safinah, Tìjān, Ajurumìyah and Arabic conjugation. I did not ask for a further clarification regarding the full titles of kitābs that Ustaz Aceng completed when studying under his cousin. Nevertheless, we are able to identify them based on their widely-use in the pesantren milieu. Safinah more likely refers to a well-known work in fiqh entitled Safinat al-najā by Salīm ibn Sumayr al-Hadramī (d. 1854). Meanwhile, Tîjān more likely refers to Tìjān al-durari by Nawawi of Banten in theology. Ajurumīyah is a well-known work in Arabic grammar authored by al-Șanhājī (d. 1324). As for his completed kitāb-gatherings in Arabic conjugation, I assume that he also completed related kitäbs that are commonly circulated in the traditional pesantren milieu.

Ajengan Uyum was a NU scholar, running a traditional pesantren. Completing his study under Ajengan Uyum, Ustaz Aceng Zakaria then continued to study under K.H.E. Abdurrahman. Ustaz Aceng Zakaria was very much impressed with the way his NU teachers conscientiously read chunks of Arabic texts in the kitäbs and carefully explained them to students.

The two brothers of Ustaz Aceng Zakaria, Ustaz Atep Tontowi and Ustaz Asep Bahroyat, also have a strong background in traditional education. Both also studied under Ajengan Uyum. Ustaz Asep Bahroyat continued study in a traditional pesantren at Keresek for about seven years. In the Persis community, Ustaz Asep Bahroyat was known for his careful reading, just like NU teachers, especially in the way he explained Arabic pronouns, for which he was popularly called ustaz damir (the pronoun teacher). ${ }^{3}$

Ustaz Romli, general principal of Pesantren Persis No. 34 in Bandung, once studied in a traditional pesantren in which one of the bandongan kitāb he followed was the Jalälayn. ${ }^{4}$ Ustaz Ujang Juanda also has a strong family background in traditional education. His brother runs the traditional pesantren, i.e. the Pesantren Darussalam in Cikajang. After graduating from Pesantren Persis No. 19 in Bentar, Ustaz Ujang continues to advocate kitāb-based learning in Pesantren Persis No. 98 in Cisurupan, Garut, where he is currently in the role 
of general principal. Along with the Jalalayn, he also delivered the Alfiyah pedagogy in the pesantren. ${ }^{5}$ All these examples point to the remarkable status of the Jalalayn within Islamic learning in Indonesia. Although many modernists would say that the bandongan Jalalayn of $\mathrm{NU}$ institutions belong to the past, the text itself appears irreplaceable as a core element of Islamic tradition that has resonance more widely than the pedagogical spaces where bandongan is maintained.

\section{Kitāb-based Learning after Indonesian Independence}

I have already elaborated how the authority of kitāb was challenged with the coming of modernisation. The adoption of classroom styles and curriculum generated different values regarding the way Islamic education should be conducted in an effective and efficient way. In this section, I show the contestation between traditional education and formal education classroom style that occurred after Indonesian independence. The core point of this contestation lies in formal administrative religious education being adopted as the preferred model in state education policy. Meanwhile, traditional learning and its kitābs were left behind, acknowledged in the state education system as non-formal education.

In the first decade after Indonesian independence there were attempts by Muslim groups to secure religious affairs in Indonesian public spheres. After the prominent 'seven words' were removed from the preamble to the 1945 Constitution, Muslim leaders struggled to seek possible ways of making Islamic affairs part of government responsibility, considering that Muslims were the majority of the population and had contributed to Indonesian independence.

Muslim representatives were consulted on these crucial issues in a discussion run by the Central Indonesian National Committee (Komite Nasional Indonesia Pusat, or KNIP), the not-chosen, but nominated preparatory parliament of the Republic of Indonesia from 1945 until the first general election in 1955, in October 1949 (Latif 2008, 25859). An issue important in this discussion was the future of religious education as, in their point of view, religious education must have legal standing and administration by the government. All Muslim members of the KNIP accepted that religious education must be administered separately from secular education and that both educational mainstreams must be treated as equal. At this important moment, this new-born 
country recognised two mainstreams in national education: secular education under the Ministry of Education and religious education under the Ministry of Religious Affairs (see also Panitia Hut ke-XXVII Departemen Agama 1973, 9-10).

As noted above, in response to the inefficient administration associated with pesantrens, the Ministry of Religious Affairs aimed to upgrade skills in Islamic school management by implementing its convergence policy (Steenbrink 1986). Starting in the 1950s, the Ministry encouraged traditional pesantrens to accept a modernised form of Islamic school (the madrasah system) through which graduates would receive a formal certificate. From this point, we can see that existence of kitāb-based learning was even further marginalised in postcolonial Indonesia.

This marginalisation manifested in a number of ways. First, the bandongan kitāb and the pesantren system remained under kin-based structures, and as such, existed in a private rather than bureaucratic domain. Authority in running this learning style belongs to the individual figure, i.e. the kiai or highest principal of the pesantren. Second, the kitāb pedagogy resists standardisation, for as I show below, it relied upon a learning process in which the student starts at the first section of the kita $\bar{b}$ and continues to the end. This is difficult to standardise. It is also difficult to precisely establish a fixed duration for when a student may achieve completion, and curriculum varied from one institution to another. Further, kitābs used as reference and learning processes greatly vary from each pesantren to another. And finally, co-presence with the famous teacher was an element of the educational experience.

Another reason the bandongan kitāb became more marginalised after Indonesian independence is connected to the way in which a learning process should produce clear skills and competencies. The bandongan kitäb has been criticised for only emphasising memorisation or completion, rather than comprehension. Also, the bandongan kitāb is fully oriented to deepening religious piety among audiences. Thus, there is no clear path for this learning style to result in a profession.

A side effect of the establishment of two streams in the national education structure in the first decade after Indonesian independence was the legitimisation of inequality justified on the basis of modernisation. The pesantrens running bandongan kitäb were forced to accommodate modernisation if their institution and graduates wished 
to receive formal acknowledgement of their qualifications. But if they did so, schooling hours in the pesantren would have to be filled with non-religious education. This meant that bandongan kitāb must be run as an extra learning activity taking place outside of regular school hours.

While the government has recognised two educational streams since the first decade of Indonesian independence, the pesantren only received formal supervision from the Ministry of Religious Affairs in 1979. At that time, the Ministry launched a new sub-directorate specifically taking care of pesantren matters. ${ }^{6}$ Although the pesantren institution received a level of support from the Ministry, the Ministry did not recognise bandongan kitäb as an equalised learning practice. As I elaborate in the next section, there are current moves by the government to include kitäb-based learning within formal education.

\section{Struggle for Educational Equality}

The government is now responding to the marginalisation of traditional learning styles in state policy. In 2007, The President of the Republic of Indonesia, Susilo Bambang Yudhoyono, issued a Government Regulation on the conduct of religious education, called the Formal Religious Education (Pendidikan Diniyah Formal, PDF). This includes kitäb-based learning and pesantren as parts of the state educational system. The recognition is even extended to education in non-formal contexts, such as the gathering hall (majelis taklim) and family environment. The government recognised these two forms of Islamic religious education as having contributed to national development. More relevant to this research, however, are regulations that structure the institutional progress of kitäb-based learning in order to locate it in a progression extending from primary level to higher education. In practice, the Formal Religious Education utilises $90 \%$ of its curriculum to study kitābs, while the remainder is allotted to general subjects.

To implement the Government Regulation, the Ministry of Religious Affairs issued two Ministerial Regulations in 2014 numbers 13 and 18 that rule how the pesantren system can be eligible to receive acknowledgement as part of the state educational system, alongside secular education and modernised Islamic education in the madrasah. These two regulations deal with the regulation of kitäb-based learning and the Ministry's project to create equivalence between the two education systems. 
The regulation formalising kitäb-based learning and its administration structures pesantren education in four levels: primary (ùlá), secondary (wustá), high ('ulyā), and tertiary (ma'had 'àlī). The equivalence policy aims to legitimise pedagogical practices conducted in pesantrens that deliver curricula outside the national curriculum, and in which pedagogical practices are provided independently under a foundation or individual figure. The pesantrens that fall into this category can be either in the modern (mu'allimin) form or traditional (salafìyah). This project is called mu'ädalah, meaning equivalence.

The project of recognising kitäb-based learning extends to other measures, such as a proposed plan to certify kiai for their expertise in certain Islamic subjects. To implement this project, the government plans to design a test for kiai. Of course, there is criticism even at this early stage. Colleagues in the pesantren environment told me that such a project will be extremely difficult to implement on the grounds that titles such as kiai or mama or ajengan are not the product of professional training or courses. Rather, social acceptance of a teacher is based on their charisma and genealogy, as well as their expertise in Islamic knowledge as a noted teacher among members of a Muslim community. My colleagues also critiqued the testing process, which is open to manipulation by applicants keen to obtain recognition. Further, there have been suggestions that the kiai should be appointed as civil servants. These policy measures indicate a reversion of the marginalisation process that has affected kitäb-based learning for a long time.

The struggle for educational equality also emerges with efforts among the traditionalist Muslims to make practices of Islamic learning in the pesantren publicly displayed. In this connection, the Jalalayn serves as the material for reading contest where the participants compete each other for the recognition of their knowledge about the book. While this event was conducted by some groups of people or organizations including the partisan of a political party, my focus here is the kitāb reading contest which within the last two decades has become a regular program by the Ministry of Religious Affairs both at the central and the regional levels.

This contest, known as the kitäb reading competition (Musabaqah Qiroatul Kutub, or MQK) gives a new meaning in the way in which the people of pesantren are given a chance to bring their traditions to 
the public sphere. The kitāb reading as a public display in contests are then taken as an important part of their pedagogical elements to train students to have self-confidence in their engagement with the books. The Indonesian government, through the Ministry of Religious Affairs, has endorsed this practice.

The Indonesian government's participation in celebrating Islamic practices can be traced to 1960s. This is when the government approved the conduct of Quranic recitation tournament, known as the Musabaqah Tilawatil Quran or MTQ. This participation then continued with the launch of the Institute of the Development of Quranic Recitation (Lembaga Pengembangan Tilawah al-Quran, or LPTQ). One of the institute's tasks is to organize public events in Quranic recitation, including the MTQ (Gade 2004, 233).

The conduct of the kitäb reading competition has been inspired by the success of the Quranic recitation tournaments. In 2004, the Ministry of Religious Affairs, in collaboration with the provincial government of West-Java, organized the first kitāb reading competition at the national level. Such events at the regional levels are regularly held for them to select eligible contestant and send them to participate in the higher and national levels.

Since the launch of the Formal Religious Education, I note that the arrangements of the kitāb reading competition started to receive some changes. These changes in the competition were made to fit the curriculum of the Formal Religious Education prescribed by the Ministry of Religious Affairs. ${ }^{7}$ The first change is that there are new branches in the current competition in 2017 representing subjects prescribed in the curriculum. Apart from that, secondly, the selection of the books for the competition materials started to follow the prescribed curriculum as well. This is different from the way this competition was held in the previous years where the books are selected based on their popularity and wide circulation in the pesantren milieu.

The fact that there is a shift in the way the books are selected for the competition leads to a change in economic behaviours of the individuals. New, but selected books have attracted more attention from the people of the pesantren to be prescribed in the school's curriculum. By so doing, they would have enough time to prepare for their students' participation in the next tournament. It is worth noting here that the participation in this tournament would increase the social prestige of 
the students who are selected as contestants. Aside from that, those who are able to finish as the winners would increase the prestige of the pesantren where the contestants are based.

\section{Ajengan Makki (Mama): An Advocate of Traditional Learning in West Java}

Traditional pedagogical practices of Islamic learning have been criticised for not positioning comprehension as a goal of learning. Despite the critics of this form of learning, traditional kitāb-based learning is still ubiquitous in Islamic learning in contemporary Indonesia. The following typological data shows the current state of Indonesian pesantrens (see Table 1).

Table 1. Pesantren in number in 2012/2013

\begin{tabular}{|l|r|}
\hline \multicolumn{1}{|c|}{ Typology } & \multicolumn{1}{c|}{ Total } \\
\hline Salafìyah & 18,233 \\
\hline Khalafiyah & 5,483 \\
\hline Kombinasi & 5,819 \\
\hline Total & 29,535 \\
\hline
\end{tabular}

Source: Statistik Pendidikan Islam Tahun 2012/2013, General Directorate of

Islamic Education, the Ministry of Religious Affairs, Republic of Indonesia.

As indicated in the above table, 18,233 of 29,535 pesantrens in Indonesia are categorised as traditional (salafìyah), while the number of pesantrens that run modern Islamic education (khalafizah) or a combination of the two (kombinasi) accounts for around 11,000 in total. This shows that most Indonesian pesantrens run the traditional kitäbgathering, regardless of whether they also provide formal education.

One prominent figure in West Java who has been dedicated to the advocacy of traditional learning is Mama Ajengan Ahmad Makki ibn Abdullah Mahfudz. His pesantren is located in the Sukabumi regency. Popularly called Mama Ajengan Ahmad Makki or Ajengan Makki, he is well-known for his efforts in building a printing company to supply kitāb loghatan to Indonesian and Sundanese speaking communities.

The term kitäb loghatan refers to the re-print kitäb that contain translation or commentary in Indonesian and Sundanese. In about 1988, Ajengan Makki built a printing company to publish kitābs to 
serve traditional learning in his pesantren. In the following years, there was increasing demand from the public for these books as educators and students found these printed editions useful for kitäb learning. He then expanded his business in kitäb loghatan-printing to cover areas in Sundanese cultural regions, in West Java and Banten. Later he expanded his market to produce Indonesian kitäb loghatan to cover wider readership in the Malay-Indonesian world.

The printing enterprise has been prosperous and productive. In a newspaper feature, a Bandung-based researcher, Iip Yahya, reported that by 2007 the Sundanese kitäbloghatan-printing project had reached 70 titles. In addition, the printing company had printed 30 titles of Indonesian kitäb loghatan (Yahya 2007). In April 2018, I was informed that the number of produced Sundanese kitāb loghatan remained stable, but the printing company was producing an increasing number of Indonesian kitāb loghatan.

Ajengan Makki has been producing kitāb loghatan for three decades, an effort that has been widely appreciated, and forms a prolonged advocacy of the traditional learning project. In this regard, Ajengan Makki (2010) stated:

Among the salafiyah pesantrens, [the Pesantren] al-Salafiyah here has the special characteristic of being able to produce the salafiyah kitäbs. [We] translate the kitäb and give them a commentary. [We] also compile some new interpretative/commentary works. So, praise be to Allah, the Pesantren al-Salafiyah is able to supply the recommended kitäb to pesantrens, especially the kitāb that are in line with the Ahl al-Sunnah wa-al-Jama'ah. ${ }^{8}$

His efforts for the cause of traditional learning have greatly contributed to the resourcing of pedagogy in the regional languages of the bilingual communities of Java. In recognition he was awarded the Rancage Literary Award in 2005 for dedication to the preservation of traditional learning practice. This award was initiated by a prominent Sundanese poet, Ajip Rosidi, and is given to those who have great dedication to preserving local literature. ${ }^{\text {? }}$

The efforts of Ajengan Makki to advocate for traditional learning can be traced back to his decision to change the name of his father's pesantren, inherited from his brothers, to Pesantren al-Salafiyah. In his understanding, the word salafiyah refers to the salaf method, which he regards as the most authentic style in Islamic learning. The change of the pesantren name does not indicate that his father did not run the 
pesantren in the same way. Instead, with this name change, Ajengan Makki clearly affirms he is an advocate of traditional learning styles that, as elaborated above, had become the object of marginalisation in the Indonesian educational system in the twentieth century.

As Pesantren al-Salafiyah No. 1 is an example of a traditional pesantren, and because its leader has pioneered remarkable regeneration of traditional learning, I chose his pesantren as a field site. While there I engaged in many discussions with students who revealed diverse ways in which the educational imbalance described above was affecting the domain of the pesantren. It could be seen in the changing ways people used titles, such as Kiai Haji (K.H.), which refers to Islamic learning, and the titles used by those graduating from university (Doctorandus or Drs.). Students stated that people now pay more attention to academic titles attached to an Islamic authority figure. This affects the amount of honorarium paid for religious services conducted. Preachers are particularly illustrative of this, as preachers lacking a contemporary academic title only receive nasi berkat (a food container usually containing rice, side dishes and banana) as honorarium. But, a white envelope containing money is added to the nasi berkat for preachers with an academic title.

How does this pesantren deal with this imbalance? It gives the opportunity for pesantren students to take formal school courses outside the pesantren. During my fieldwork, the pesantren coordinator informed me that students of the Pesantren al-Salafiyah No. 1 were predominantly part-time students who also undertake formal study outside the pesantren. This contrasts greatly with the situation of several years ago when most students of the pesantren were predominantly fulltime students and not undertaking formal schooling.

\section{Conclusion}

Kitāb-based learning has suffered from inequality within the national education system as a result of modernisation of Islamic education in Indonesia since the early twentieth century. The coming of Islamic modernism to Indonesia led to development of classroom styles for the study of Islam, which placed priority on effective and efficient learning within structured curricula. As a result, core aspects of traditional Islamic learning were considered no longer appropriate, one being the use of kitäbs as learning texts. In modern environments, 
textbooks that support prescribed curriculums are valued and this has diminished the importance of kitäbs as sources of Islamic authority. With regard to learning styles, the traditional format of kitāb-based learning, i.e. bandongan, was not easily incorporated into the modern system. Modern Islamic educators, supporting styles similar to those of the state (non-religious) education system, considered this learning style as ineffective and inefficient. As a result, graduates from traditional institutions lack the qualifications needed to compete in the contemporary job market.

This inequality is not solely a matter of differing pedagogical styles, for it reflects rivalling Islamic currents. Modernist education environments were established by organisations with a preference for reformist ideology, as opposed to certain schools of Islamic legal and scholarly thought. The Jalalayn is an interesting case study in this regard. It is an icon of traditionalist Islam, but at the same time has a higher level of acceptance in modern environments than many other kitābs.

Since the early twentieth century, modernisation has given high preference to classroom styles of learning. Modern schools preferred to utilise textbooks that serve objectives of learning based on applied curriculum. These are mostly current publications that can be easily applied in the classroom learning style. This new way of learning greatly diminished the authority of kitāb which for centuries held unquestionable authority for the study of Islam. In this new environment, kitāb-based learning was a difficult fit with modern education and was therefore considered ineffective and inefficient.

As new ways of learning that adopted modern management became more dominant, there was a push for kitābs to be accepted in modern Islamic schools. However, the reception of modernisation was linked to ideas of Islamic modernism that diminished the importance of kitābs. Most kitābs were accordingly removed from the curriculum because they did not suit modern Islamic principles. Some kitāb, such as the Tafsìr al-Jalälayn have shown the strength and flexibility needed to sustain their relevance to both traditional and modern Islamic education.

The traditional kitäb-based learning was criticised for resistance to standardisation characterising the national education system. First, this learning style is part of the pesantren system that remains the domain of individual and kin-based structures. Second, bandongan kitäb aims to 
serve the goal of completion where the learning process usually starts at the first section of the kitāb and continues to the end. As kitābs greatly vary in number of pages, it is difficult to standardise and fix learning duration between one bandongan kitäb and another. Bandongan kitäb also run at the teacher's convenience regarding start and to end. Further, the goal of this learning style is not oriented to seek a career or profession.

In the early twenty-first century there were efforts by the Ministry of Religious Affairs to equalise kitāb-based learning in the state educational system. By obtaining this educational equality, graduates of pesantrens that only run bandongan kitäb had educational opportunities for a future profession and career. Two projects have been launched by the Ministry to take over administration of the pesantren through formation of the Formal Religious Education and the equivalence project. 


\section{Endnotes}

- The earlier version of this article is part of my Ph.D. thesis submitted to Monash University in 2018 entitled "Jalälayn pedagogical practice: Styles of Quran and tafsir learning in contemporary Indonesia”. I express my grateful thanks to Associate Professor Julian Millie, Professor Peter G. Riddell and anonymous reviewers for suggestions and comments. My grateful thanks are also addressed to the Indonesian Endowment Fund for Education (Lembaga Pengelola Dana Pendidikan, or LPDP) for financial supports. However, I take responsibility for all shortcomings found in this work.

1. I interviewed Ustaz Aceng Zakaria on 1 December 2015 in Garut and Ustaz Romli on 11 February 2017 in Bandung.

2. I am grateful to my Persis informants, and especially Ustaz Moh. Iqbal Santoso, for this insight. Ustaz Iqbal, who considers himself a supporter of classroom styles, is currently general principal of Pesantren Persis No. 76 in Tarogong, Garut.

3. Interview with Ustaz Aceng Zakaria on 1 December 2015 in Garut.

4. Interview with Ustaz Romli on 11 February 2017 in Bandung.

5. Interview with Ustaz Ujang Juanda on 1 February 2017 in Garut.

6. For the formation of the sub-directorate for pesantren in the Ministry of Religious Affairs, see $<$ http://ditpdpontren.kemenag.go.id/profil-direktorat-pd-pontren/2017>. (Accessed 26 January 2018).

7. Based mainly on findings during my observation of the MQK at the regional level in Ciamis in 2017 and interview with the officer of the Ministry of the Religious Affairs, Dr. Suwendi, on May $9^{\text {th }}$ in Jakarta.

8. Pondok Pesantren Assalafiyyah Babakan Tipar Sukabumi. Youtube. <https://www. youtube.com/watch?v=T_BvnbicB_s.> (accessed 21 May 2018). English translation from spoken Indonesian is made by Nurtawab.

9. On the Rancage Literary Award, see Kementerian Pendidikan dan Kebudayaan Republik Indonesia. (n.d.). Ensiklopedia Sastra Indonesia. http://ensiklopedia.kemdikbud.go.id/ sastra/artikel/Hadiah_Sastra_Rancage. (Accessed 10 April 2018).

\section{Bibliography}

Azra, Azyumardi. 2003. Surau: Pendidikan Islam Tradisional Dalam Transisi Dan Modernisasi. Ciputat: Logos.

Azra, Azyumardi, Dina Afriyanti, and Robert W. Hefner. 2007. "Pesantren and Madrasa: Muslim Schools and National Ideals in Indonesia." In Schooling Islam: The Culture and Politics of Modern Muslim Education, Princeton: Princeton University Press.

Bachtiar, T.A. 2012. Sejarah Pesantren PERSIS 1936-1983. Jakarta: Pembela Islam Media.

Burhanudin, Jajat. 2010. "Traditional Islam and Modernity: Some Notes on the Changing Role of the Ulama in Early Twentieth Indonesia." In Varieties of Religious Authority: Changes and Challenges in 20th Century Indonesian Islam, eds. Azyumardi Azra, C. van Dijk, and N. J. G Kaptein. Singapore: Institute 
of Southeast Asian Studies.

Dhofier, Zamakhsyari. 1999. The Pesantren Tradition: The Role of the Kyai in the Maintenance of Traditional Islam in Java. Arizona: Program for Southeast Asian Studies.

Fealy, Greg. 1998. "Ulama and Politics in Indonesia: A History of Nahdlatul Ulama, 1952-1967.” Ph.D. Dissertation. Monash University.

Federspiel, Howard M. 1970. Persatuan Islam; Islamic Reform in Twentieth Century Indonesia. Ithaca: Cornell University Press.

. 2001. Islam and Ideology in the Emerging Indonesian State: The Persatuan Islam (Persis), 1923-1957. Leiden; Boston: Brill. http://site.ebrary.com/ id/10090621 (December 12, 2019).

Gade, Anna M. 2004. Perfection Makes Practice: Learning, Emotion, and the Recited Qurān in Indonesia. Honolulu: University of Hawai'i Press.

Hefner, Robert W. 2009. Making Modern Muslims: The Politics of Islamic Education in Southeast Asia. Honolulu: University of Hawaii Press.

Hefner, Robert W., and Muhammad Qasim Zaman, eds. 2007. Schooling Islam: The Culture and Politics of Modern Muslim Education. Princeton, N.J: Princeton University Press.

Kaptein, N. J. G. 2004. The Voice of Ulama: Fatwas and Religious Authority in Indonesia. Singapore: Institute of Southeast Asian Studies.

Latif, Yudi. 2008. Indonesian Muslim Intelligentsia and Power. Singapore: Institute of Southeast Asian Studies.

Machasin. 2010. "Struggle for Authority: Between Formal Religious Institution and Informal-Local Leaders." In Varieties of Religious Authority: Changes and Challenges in 20th Century Indonesian Islam, eds. Azyumardi Azra, C. van Dijk, and N. J. G Kaptein. Singapore: Institute of Southeast Asian Studies.

Noer, Deliar. 1980. Gerakan Modern Islam di Indonesia 1900-1942. Jakarta: LP3ES.

2010. Administration of Islam in Indonesia. Jakarta: Equinox Publishing.

Panitia Hut ke-XXVII Departemen Agama RI. 1973. 27 Tahun Departemen Agama: 19463 Januari 1973. Jakarta: Departemen Agama RI.

Roff, William R. 1967. The Origins of Malay Nationalism. Kuala Lumpur: University of Malaya Press.

Rosyidin, Didin Nurul. 2009. Konsep Pendidikan Formal Islam: Ikhtiar Pendidikan 
Formal Persis Dalam Mencetak Generasi Tafaqquh Fiddin. Bandung: Pustaka Nadwah.

Steenbrink, Karel. 1986. Pesantren, Madrasah, Sekolah: Pendidikan Islam Dalam Kurun Modern. Jakarta: LP3ES.

Wirjosukarto, A.H. 1966. Pembaharuan Pendidikan Dan Pengadjaran Islam Oleh Pergerakan Muhammadijah. Malang: U.P. Ken Mutia.

Yahya, I.D. 2007. "Kisah Kerajaan Ngalogat.” Pikiran Rakyat.

Yunus, Mahmud. 1979. Sejarah Pendidikan Islam Indonesia. Jakarta: Mutiara.

\section{Legislation}

Keputusan Direktur Jenderal Pendidikan Islam Nomor 6036 Tahun 2015 tentang Kerangka Dasar dan Struktur Kurikulum Pendidikan Diniyah Formal Ulya (The Decree of the General Director of Islamic Education No. 6036 year 2015 on the Structure and Curriculum of the Formal Religious Education at the Senior level).

Keputusan Direktur Jenderal Pendidikan Islam Nomor 6963 Tahun 2017 tentang Kerangka Dasar dan Struktur Kurikulum Pendidikan Diniyah Formal Wustha (The Decree of the General Director of Islamic Education No. 6963 year 2017 on the Structure and Curriculum of the Formal Religious Education at the Junior level).

Peraturan Menteri Agama Republik Indonesia Nomor 13 Tahun 2014 tentang Pendidikan Keagamaan Islam (The Regulation of the Minister of Religious Affairs, the Republic of Indonesia, No. 13 year 2014 on Islamic education).

Peraturan Menteri Agama Republik Indonesia Nomor 18 Tahun 2014 tentang Satuan Pendidikan Mu'adalah pada Pondok Pesantren (The Regulation of the Minister of Religious Affairs, the Republic of Indonesia, No. 18 year 2014 on the Mu'adalah education in the Pondok Pesantren).

Peraturan Pemerintah Republik Indonesia Nomor 55 Tahun 2007 tentang Pendidikan Agama dan Pendidikan Keagamaan (The Regulation of the Government of the Republic of Indonesia No. 55 year 2007 on Religion Education and Religious Education).

\section{Interviews}

Interview with Ustaz Aceng Zakaria, Garut, December 1 ${ }^{\text {st }}, 2015$.

Interview with Ustaz Romli, Bandung, February 11 $1^{\text {th }}, 2017$.

Interview with Ustaz Ujang Juanda, Garut, February 1 1, 2017. 
Interview with Ustaz Iqbal Santoso, Garut, February 6 ${ }^{\text {th }}, 2017$.

Interview with Dr Suwendi, officer in the Ministry of Religious Affairs, Jakarta, May $9^{\text {th }}, 2017$.

Ervan Nurtawab, State Institute for Islamic Studies (IAIN) Metro, Indonesia; Monash University, Australia. Email: ervan_nur@yahoo.com. 


\section{Guidelines}

\section{Submission of Articles}

tudia Islamika, published three times a year since 1994, is a bilingual (English and Arabic), peer-reviewed journal, and specializes in Indonesian Islamic studies in particular and Southeast Asian Islamic studies in general. The aim is to provide readers with a better understanding of Indonesia and Southeast Asia's Muslim history and present developments through the publication of articles, research reports, and book reviews.

The journal invites scholars and experts working in all disciplines in the humanities and social sciences pertaining to Islam or Muslim societies. Articles should be original, research-based, unpublished and not under review for possible publication in other journals. All submitted papers are subject to review of the editors, editorial board, and blind reviewers. Submissions that violate our guidelines on formatting or length will be rejected without review.

Articles should be written in American English between approximately 10.000-15.000 words including text, all tables and figures, notes, references, and appendices intended for publication. All submission must include 150 words abstract and 5 keywords. Quotations, passages, and words in local or foreign languages should 
be translated into English. Studia Islamika accepts only electronic submissions. All manuscripts should be sent in Ms. Word to: http:// journal.uinjkt.ac.id/index.php/studia-islamika.

All notes must appear in the text as citations. A citation usually requires only the last name of the author(s), year of publication, and (sometimes) page numbers. For example: (Hefner 2009a, 45; Geertz 1966, 114). Explanatory footnotes may be included but should not be used for simple citations. All works cited must appear in the reference list at the end of the article. In matter of bibliographical style, Studia Islamika follows the American Political Science Association (APSA) manual style, such as below:

1. Hefner, Robert. 2009a. "Introduction: The Political Cultures of Islamic Education in Southeast Asia," in Making Modern Muslims: The Politics of Islamic Education in Southeast Asia, ed. Robert Hefner, Honolulu: University of Hawai'i Press.

2. Booth, Anne. 1988. "Living Standards and the Distribution of Income in Colonial Indonesia: A Review of the Evidence." Journal of Southeast Asian Studies 19(2): 310-34.

3. Feener, Michael R., and Mark E. Cammack, eds. 2007. Islamic Law in Contemporary Indonesia: Ideas and Institutions. Cambridge: Islamic Legal Studies Program.

4. Wahid, Din. 2014. Nurturing Salafi Manhaj: A Study of Salafi Pesantrens in Contemporary Indonesia. PhD dissertation. Utrecht University.

5. Utriza, Ayang. 2008. "Mencari Model Kerukunan Antaragama." Kompas. March 19: 59.

6. Ms. Undhang-Undhang Banten, L.Or.5598, Leiden University.

7. Interview with K.H. Sahal Mahfudz, Kajen, Pati, June $11^{\text {th }}$, 2007.

Arabic romanization should be written as follows:

Letters: ', $b, t, t h, j, h, k h, d, d h, r, z, s, s h, s, d, t, z, ', g h, f, q, l$, $m, n, h, w, y$. Short vowels: $a, i, u$. long vowels: $\bar{a}, \overline{\mathrm{i}}, \overline{\mathrm{u}}$. Diphthongs: $a w$, ay. Tà marbūtāa: t. Article: al-. For detail information on Arabic Romanization, please refer the transliteration system of the Library of Congress (LC) Guidelines. 
ستوديا إسلاميكا (ISSN 0215-0492; E-ISSN: 2355-6145) مجلة علمية دولية محكمة تصدر عن مركز دراسات الإسلام والمجتمع (PPIM) بجامعة شريف هداية الله الإسلامية الحكومية بجاكرتا، تعنى بدراسة الإسلام في إندونيسيا خاصة وفي جنوب شرقي آسيا عامة. وتستهدف المجلة نشر البحوث العلمية الأصيلة والقضايا المعاصرة حول الموضوع، كما ترحب بإسهامات الباحثين أصحاب التخصصات ذات الصلة. وتخضع جميع الأبحاث المقدمة للمجلة للتحكيم من قبل لجنة مختصة.

تم اعتماد ستوديا إسلاميكا من قبل وزارة البحوث والتكنولوجيا والتعليم العالي بجمهورية إندونيسيا باعتبارها دورية علمية (رقم القرار: 32a/E/KPT/2017).

ستوديا إسلاميكا عضو في CrossRef (الإحالات الثابتة في الأدبيات الأكاديمية) منذ ع ا • ب، وبالتالي فإن جميع المقالات التي نشرتا مرقمة حسب معرّف الوثيقة الرقمية (DOI). ستوديا إسلاميكا بجلة مفهرسة في سكوبس (Scopus) منذ .ب مايو 0 . ب.

$$
\begin{aligned}
& \text { قيمة الاشتر الك السنوي خارج إندونيسيا: }
\end{aligned}
$$

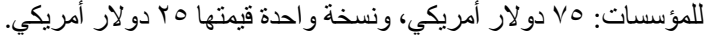

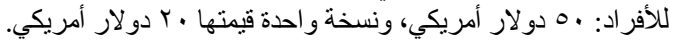

$$
\begin{aligned}
& \text { والقيمة لا تشمل نفقة الإرسال بالبريد الجوي. ونسي. }
\end{aligned}
$$

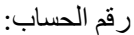

$$
\begin{aligned}
& \text { خارج إندونيسيا (دولار أمريكي): ابن }
\end{aligned}
$$

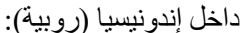

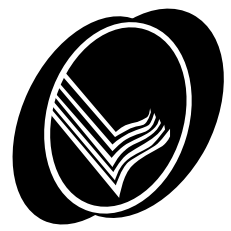




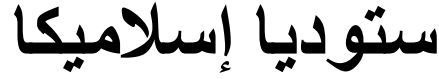 \\ مجلة إندونيسيا للار اسات الإسلامية}

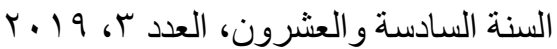

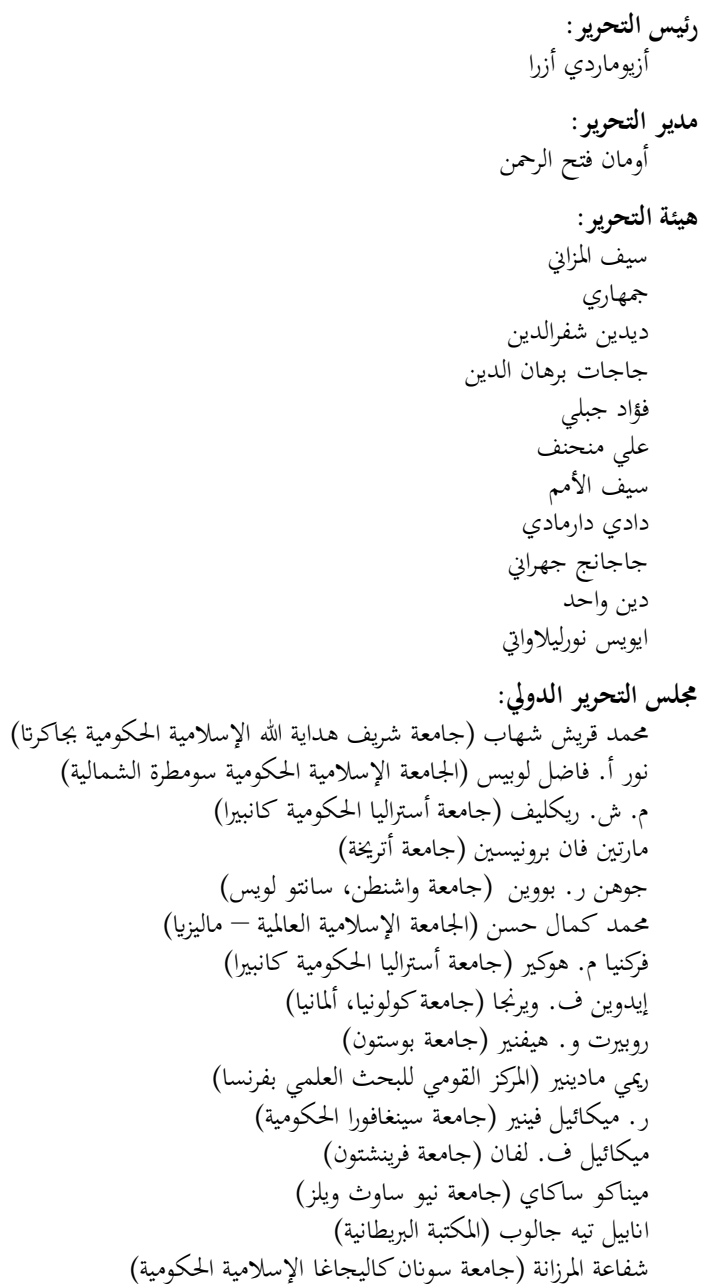

مساعد هيئة التحرير:

تيستريونو

محمد نداء فضلان

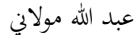

مراجعة اللغة الإنجليزية:

بنيمن ج. فريمان

دانيل فتريون

موسى بتول

مراجعة اللغة العربية:

توباغوس أدي أسناوي

تصميم الغلاف:

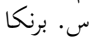





\section{لالتوايا السال|مسيا}




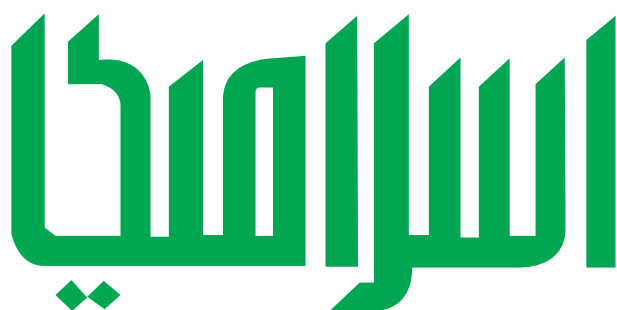

السنة السادسة والعشرون، العدد ب، 9 1 بـ

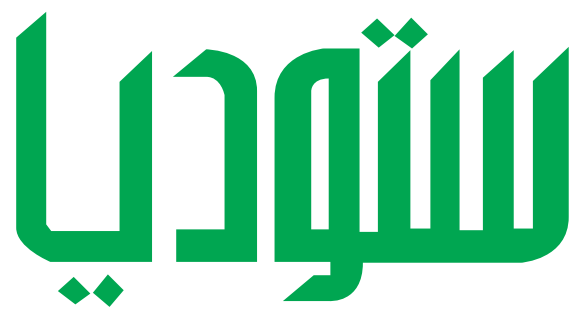

بجلة إنلدونيسية للدراسات الإسلامية

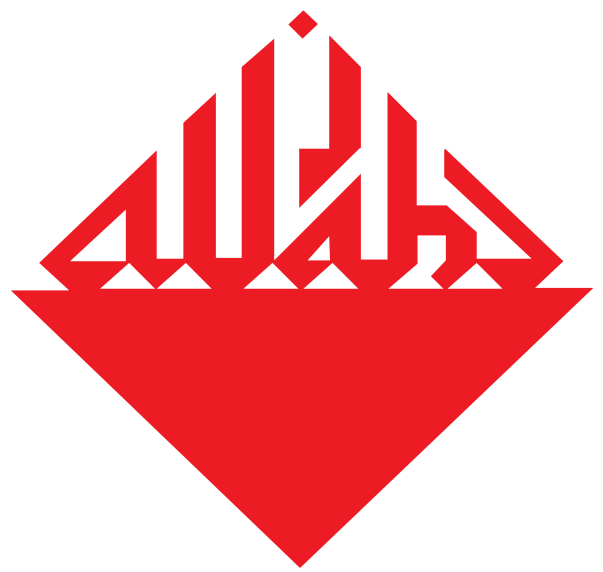

الشبكائ الاجتماعية والمنحرية

Sumatera y Lombok بيلن هسلمين

كاسة كيم تهنة وهنطوط Sasak جمال الدين 